\title{
Every Child Matters: Change for Children in Schools
}

department for education and skills

creating opportunity, releasing potential, achieving excellence 
Front Cover Foulstone Mural photograph: Gavin Joynt. 


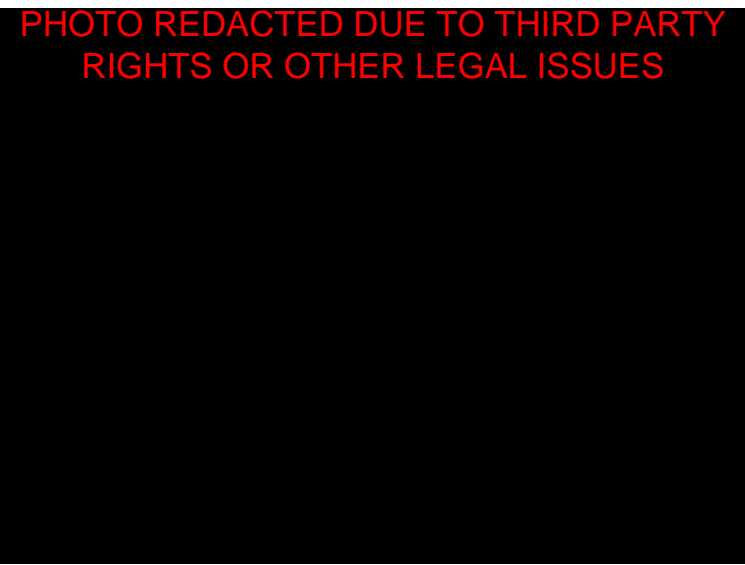

Every child matters, the Government's vision for children's services, was published in September 2003. It proposed reshaping children's services to help achieve the outcomes children and young people told us are key to well-being in childhood and later life.

- Be healthy

- Stay safe

- Enjoy and achieve

- Make a positive contribution

- Achieve economic well-being

The Government has legislated for changes in the way children's services work together. Every Child Matters: Change for Children explains how the new Children Act 2004 forms the basis of a long-term programme of change. This document is one of a series that describe the implications for different services. All of these documents and others referred to in the text are available at www.everychildmatters.gov.uk. Whether you are a headteacher, a teacher, a teaching assistant, a member of the support staff or a governor, everyone in a school has a role to play.

\section{Improving outcomes for children and young people}

Pupil performance and well-being go hand in hand. Pupils can't learn if they don't feel safe or if health problems are allowed to create barriers. And doing well in education is the most effective route for young people out of poverty and disaffection. Every Child Matters: Change for Children will strongly support the principle of personalisation and the work schools are already doing to raise educational standards by:

- encouraging schools to offer a range of extended services that help pupils engage and achieve, and building stronger relationships with parents and the wider community; and

- supporting closer working between universal services like schools and specialist services so that children with additional needs can be identified earlier and supported effectively. 


\section{We want every child to fulfil their potential, regardless of their background or circumstances}

The thinking behind Every Child Matters: Change for Children is not new. High expectations and a broad view of supporting children and young people are common features of highly successful schools. Schools already contribute to pupils' wider well-being through, for example:

- helping each pupil achieve the highest educational standards they possibly can;

- dealing with bullying and discrimination and keeping children safe;

- becoming Healthy Schools and promoting healthy lifestyles through Personal, Social and Health Education lessons, drugs education, breakfast clubs and sporting activities;

- ensuring attendance, encouraging pupils to behave responsibly, giving them a strong voice in the life of the school and encouraging them to volunteer to help others;

- helping communities to value education and be aware that it is the way out of the poverty trap;

- engaging and helping parents in actively supporting their children's learning and development.

New inspection arrangements currently under discussion in Parliament mean that the criteria for school inspection would in future cover the contribution schools make to pupil well-being. This would be reflected in school's self-evaluation. The new school Profile, now being tested, will give schools the chance to set out for parents the full range of services they offer.

The Government is currently piloting discussions between schools and local School Improvement Partners on a school's individual improvement priorities as part of a "new relationship with schools". This is designed to encourage a professional analysis of how the school is serving its pupils and the priorities for improvement. The data used to inform these discussions will help identify how well different groups of pupils are progressing and whether there are barriers to pupils' learning that can be tackled by supporting their wider well-being.

A particular issue for all schools, including independent schools, is the new statutory duty on schools in the Education Act 2002 to safeguard children, to promote their welfare and to ensure everyone plays their full part in safeguarding children from abuse and neglect. The Department for Education and Skills issued guidance to schools in September 2004 to support them in putting this into practice.

\section{Success depends on services working together}

The local context in which schools are working will change as Local Authorities develop children's trust arrangements to integrate front-line services, backed up by integrated processes, planning and interagency governance. Trusts will work together with local partners from the public, private, voluntary and community sectors to assess local needs, agree priorities and commission local services to meet those priorities. From April 2006 these will be reflected in a new Children and Young People's Plan that brings together all Local Authority's planning for children and young people. 
The Government expects children's trust arrangements to be developed in most areas by 2006 and all areas by 2008. This will mean for schools:

- children's trust arrangements involving schools in local partnerships so that schools can feed their views into local service planning and, if they wish, provide services individually or in partnership with other schools;

- children's trust arrangements and schools working together to find places for hard-to-place pupils. The Government would like local protocols for hard-to-place pupils to be agreed by September 2005; and

- Local Authorities working closely with schools in fulfilling their duty to promote the educational achievement of looked-after children.

Integrating services should mean more effective support for pupils with complex needs who require multi-agency support. Two common processes that should make this easier are:

- a Common Assessment Framework to help schools identify when a pupil's needs can be met within the school and to enable better targeted referral to other specialist services when needed so they can respond more effectively. The framework will be published in 2005 with the expectation that Local Authorities will introduce it in their areas by 2008;

- cross-government guidance on information-sharing to improve the sharing of information between schools and other agencies about individual children with additional needs. In time this is likely to be supported by new databases or indexes containing basic information about each child or young person that will enable schools to make contact more easily with other practitioners involved.

In re-thinking service provision, Local Authorities will be developing with their partners the use of a lead professional to ensure that a child with additional needs receives co-ordinated support from different agencies. A lead professional may come from the school or from a partner agency, whichever is the more appropriate.

\section{Next steps}

Schools and their governing bodies will want to consider what changes are happening locally so that they will be in a position to collaborate with the Local Authority as it develops its children's trust arrangements. A particular area of interest will be the development of extended services in and around schools. Many schools already offer aspects of extended services such as breakfast and after-school clubs which are shown to improve children's motivation and engagement.

The Government is looking to all schools, over time, to provide a core offer of extended services either on site or across a cluster of local schools and providers. For primary schools this core offer includes study support, family learning and parental support opportunities, and better referral systems to multiagency support where needed. For secondary schools, the core offer is similar, encouraging schools to open up facilities such as sports, arts and ICT. 
The recently announced ten year strategy for childcare sets out the ambition that by 2008 half of parents of children aged 5-11 will be able to access childcare at their child's primary school, or at a nearby school or provider with supervised transfer arrangements, at least between 8am-6pm, all year round. Childcare will not necessarily be on the school site but could be provided locally in collaboration with other providers. All parents will have this opportunity by 2010. By 2008, at least a third of secondary schools will be open on the same basis offering a broad range of things for young people to do. It is envisaged that by 2010 all secondary schools will provide this offer.

The ten year strategy for childcare also promises an enhanced free early education entitlement for three and four year olds that parents will be able to access flexibly - 15 hours a week across 38 weeks by 2010 with a longer-term goal of 20 hours per week. Schools providing early education for three and four year olds will need to consider, with support from their Local Authority, the changes that they will need to make to accommodate this offer.

An extended schools prospectus, to set out the extended schools strategy and the support available, will be launched early in 2005. The Youth Green Paper, also to be published early in 2005, will set out what the offer should be for the older child.

\section{Workforce implications}

The DfES will continue to work with the signatories to the national workforce remodelling agreement on developing extended services in schools. There is no intention to create additional burdens for school leaders or other staff. Workforce remodelling should encourage more integrated working and will have a significant role to play in supporting changes in practice. 


\section{Further information}

Below is a more detailed description of the five outcomes. They are part of the Every Child Matters: Change for Children Outcomes Framework used by children's services inspectorates to shape the criteria for new Joint Area Reviews of local areas.

\begin{tabular}{|c|c|}
\hline \multirow[t]{6}{*}{ Be healthy } & Physically healthy \\
\hline & Mentally and emotionally healthy \\
\hline & Sexually healthy \\
\hline & Healthy lifestyles \\
\hline & Choose not to take illegal drugs \\
\hline & Parents, carers and families promote healthy choices \\
\hline \multirow[t]{6}{*}{ Stay safe } & Safe from maltreatment, neglect, violence and sexual exploitation \\
\hline & Safe from accidental injury and death \\
\hline & Safe from bullying and discrimination \\
\hline & Safe from crime and anti-social behaviour in and out of school \\
\hline & Have security, stability and are cared for \\
\hline & Parents, carers and families provide safe homes and stability \\
\hline \multirow[t]{6}{*}{ Enjoy and achieve } & Ready for school \\
\hline & Attend and enjoy school \\
\hline & Achieve stretching national educational standards at primary school \\
\hline & Achieve personal and social development and enjoy recreation \\
\hline & Achieve stretching national educational standards at secondary school \\
\hline & Parents, carers and families support learning \\
\hline \multirow[t]{6}{*}{ Make a positive contribution } & $\begin{array}{l}\text { Engage in decision-making and support the community and } \\
\text { environment }\end{array}$ \\
\hline & Engage in law-abiding and positive behaviour in and out of school \\
\hline & $\begin{array}{l}\text { Develop positive relationships and choose not to bully and } \\
\text { discriminate }\end{array}$ \\
\hline & $\begin{array}{l}\text { Develop self-confidence and successfully deal with significant life } \\
\text { changes and challenges }\end{array}$ \\
\hline & Develop enterprising behaviour \\
\hline & Parents, carers and families promote positive behaviour \\
\hline \multirow[t]{6}{*}{ Achieve economic well-being } & $\begin{array}{l}\text { Engage in further education, employment or training on leaving } \\
\text { school }\end{array}$ \\
\hline & Ready for employment \\
\hline & Live in decent homes and sustainable communities \\
\hline & Access to transport and material goods \\
\hline & Live in households free from low income \\
\hline & Parents, carers and families are supported to be economically active \\
\hline
\end{tabular}


The new Children Act 2004 is the legislative spine for the reforms, supporting:

- partnership: Local Authorities working with local partners to agree local priorities for improving outcomes and commissioning services for children, young people and parents;

- accountability: Local Authorities appointing by 2008 at the latest Directors of Children's Services and Lead Members to provide vision and impetus for local change;

- a sharper focus on safeguarding children: statutory Local Safeguarding Children's Boards will replace the current Area Child Protection Committees;

- inspection: new Joint Area Reviews of children's services will assess how successfully services are working together to improve outcomes.

More detail is available in Every Child Matters: Change for Children available at www.everychildmatters.gov.uk. This contains the timetable for consultations and details concerning the timing of the new duties. A downloadable presentation is also available.

Guidance to schools on safeguarding, issued in September 2004, can be found through the Every Child Matters website.

Information on the work of the National Remodelling Team is available at www.remodelling.org.

Case studies about how to develop extended services in schools can be found on www.teachernet.gov.uk/extendedschools.

Information about health is contained in the National Service Framework for Children, Young People and Maternity Services and the recent Public Health White Paper Choosing Health: making healthy choices easier. These can be found on the Department of Heath site at www.dh.gov.uk 
Other Titles in this series include:

Every Child Matters:

Change for Children

Ref: DfES/1081/2004

ISBN: 1844783553

Every Child Matters:

Change for Children

in Social Care

Ref: DfES/1090/2004

ISBN: $184478357 X$

Every Child Matters:

Change for Children

in the Criminal Justice System

Ref: DfES/1092/2004

ISBN: 1844783596

Every Child Matters:

Change for Children

in Health Services

Ref: DfES/1091/2004

ISBN: 1844783588 

You can download this publication or order copies online at www.teachernet.gov.uk/publications

Search using the ref: DfES/1089/2004

Copies of this publication can also be obtained from:

DfES Publications

PO Box 5050

Sherwood Park

Annesley

Nottingham NG15 0DJ.

Tel: 08456022260

Fax: 08456033360

Textphone: 08456055560

email: dfes@prolog.uk.com

Please quote ref: DfES/1089/2004

ISBN: 1844783561

PPAPG/D16(5752)/1204/63

(C) Crown copyright 2004

Produced by the Department for Education and Skills

Extracts from this document may be reproduced for non commercial education or training purposes on the condition that the source is acknowledged. 